\title{
PENGARUH PROSES PENGOLAHAN TERHADAP SIFAT FISIKA DAN KIMIA BUBUK KEDELAI: LITERATURE REVIEW
}

Gede Yohanes Arygunartha ${ }^{1}$, Ni Luh Putu Putri Setianingsih ${ }^{2}$, Sofia Utami Putri Sunarso ${ }^{3}$

${ }^{1}$ Sekolah Vokasi, Universitas Warmadewa, Bali, Indonesia

2,3Fakultas Pertanian, Universitas Warmadewa, Bali, Indonesia

anez.ary25@gmail.com,putriameell@gmail.com, sofiau188@gmail.com

\begin{tabular}{|c|c|c|}
\hline & & Abstract \\
\hline Received: & O3-02-2022 & \multirow[b]{3}{*}{$\begin{array}{l}\text { Soybean powder is a functional product which contains } \\
\text { high protein and isoflavones. Protein and isoflavones } \\
\text { can prevent chronic and degenerative diseases. The } \\
\text { processing can affect the composition especially protein } \\
\text { and isoflavones mainly the physical properties of } \\
\text { soybean powder. The purpose of the research was to } \\
\text { evaluate the effect of processing on the physical and } \\
\text { chemical properties in order to produce soybean } \\
\text { powder to develop the applications in foodand } \\
\text { pharmaceutical industries. The soybean was processed } \\
\text { through a few treatments, roasting,soaking, steaming, } \\
\text { boiling, and without treatments as a comparator. The } \\
\text { results showed that the processing of immersion, } \\
\text { roasting, steaming, and boiling decreased bulk density } \\
\text { until o.o6, wettability } 8 \text { seconds, protein content } \\
\text { 1o.87\%, and crude fiber } 4.85 \% \text {. However, the isoflavone } \\
\text { content of soybean powder increased to o.o77\% and } \\
\text { water content } 2.18 \% \text { compared to soybeanpowder } \\
\text { without processing. }\end{array}$} \\
\hline Accepted: & $04-02-2022$ & \\
\hline $\begin{array}{l}\text { Published: } \\
\text { Keywords: }\end{array}$ & $\begin{array}{l}20-02-2022 \\
\text { soybean powder, } \\
\text { processing, } \\
\text { physical } \\
\text { properties, } \\
\text { chemical } \\
\text { properties }\end{array}$ & \\
\hline
\end{tabular}

\section{Abstrak}

Kata bubuk kedelai,

kunci: $\quad$ pengolahan, sifat

fisika, sifat kimia
Bubuk kedelai merupakan produk fungsional mengandung protein yang tinggi dan isoflavon. Protein dan isoflavon dapat mencegah penyakit kronis dan degeneratif. Proses pengolahan dapat mempengaruhi komposisi terutama protein dan isoflavon serta sifat fisika dari bubuk kedelai. Tujuan penelitian ini adalah untuk mengevaluasi pengaruh proses pengolahan terhadap sifat fisika dan kimia kedelai bubuk guna mengembangkan aplikasi dalam industri makanan dan farmasi. Kedelai diolah dengan beberapa proses, yaitu: penyangringan, perendaman, pengukusan dan perebusan, serta tanpa pengolahan sebagai pembanding. Hasil penelitian menunjukkan bahwa proses perendaman, penyangraian, pengukusan dan perebusan menurunkan densitas kamba hingga 0,06, wettability 8 detik, kadar protein 10,87\%dan serat kasar 4,85\%. Akan tetapi, kandungan isoflavon bubuk kedelai naik hingga 0,077\% dan kadar air 2,18\% dibandingkan dengan bubuk tanpa pengolahan.

Corresponding Author: Gede Yohanes Arygunartha

E-mail: anez.ary25@gmail.com 


\section{PENDAHULUAN}

Kedelai (Glycine $\max (L)$ Merill) sebagai sumber pangan protein tinggi mengandung lisin, treonin yang lebih tinggi dibandingkan kacang-kacangan (Cederroth \& Nef, 2009). Selain sumber zat gizi, kedelai juga merupakan pangan fungsional karena memiliki senyawa bioaktif isoflavon terbesar diantara tanaman lainnya yang bersifat sebagai antioksidan penghambat penyakit degeneratif, kontrol glikemik, dan menurunkan kadar kolesterol dalam darah (Cederroth \& Nef, 2009). Menurut United States Department of Agriculture (USDA, 1999), tiap $100 \mathrm{~g}$ kedelai mentah mengandung $128.35 \mathrm{mg}$ isoflavon.

Daya terima konsumen Indonesia terhadap kedelai bubuk sebelum pengolah relatif masih rendah. Salah satu penyebab kedelai kurang disukai adalah baunya yang langu (beany flavor), sehingga memerlukan proses pengolahan sebelum dikonsumsi. Proses pengolahan pada komoditi pangan dapat menurunkan zat gizi dari bahan tersebut, tetapi juga dapat meningkatkan daya cerna terhadap pangan (Palupi, Zakaria, \& Prangdimurti, 2007). Prinsip pengolahan bertujuan untuk mengawetkan, memudahkan dalam pengemasan, penyimpanan dan distribusi pangan serta untuk meningkatkan nilai organoleptiknya. Pada kacangkacangan, pengolahan dapat menurunkan senyawa anti nutrisi yang terkandung di dalamnya yaitu antitripsin, hemaglutinin, asam fitat dan oligosakarida penyebab flatulesi (kembung) (Sukandar et al., 2010); (Shimelis \& Rakshit, 2007).

Proses berbeda dalam pembuatan bubuk kedelai diduga dapat memberikan tingkat kerusakan dan komposisi kimia yang berbeda. Selama proses perendaman dan perebusan terjadi perpindahan massa dan peningkatan protein larut sehingga meningkatkan daya cerna protein dan komponen lainnya. Menurut (de Lima, Kurozawa, \& Ida, 2014), perendaman kedelai pada suhu sekitar $250 \mathrm{C}$ selama 1 jam tidak memberikan pengaruh yang signifikan, akan tetapi perendaman pada suhu 550C selama 3 jam dapat menaikkan kandungan isoflavon aglikon.

\section{METODE PENELITIAN}

Metode yang digunakan dalam penulisan karya ilmiah ini adalah dengan studi literatur dan melakukan percobaan langsung mengenai topik. Bahan yang digunakan dalam penelitian ini ialah biji kedelai, kemasan, dan bahan kimia penguji adalah $\mathrm{HCl}, \mathrm{NaOH}$, $\mathrm{H}_{2} \mathrm{SO}_{4}$, dan selen. Peralatan yang digunakan diantaranya HPLC, labu Kjedahl, oven, gelas ukur, pavodest, erlenmeyer dan alat gelas lainnya.

\section{Pelaksanaan Penelitian}

Biji kedelai disortir dari biji yang rusak, cacat dan benda asing. Proses kedelai tanpa pengolahan, biji langsung dihaluskan, diayak, dan dikeringkan. Perlakuan kedelai dengan penyangraian, biji disangrai terlebih dahulu selama 20-30 menit dengan api kecil sampai sedang, selanjutnya dihaluskan, disaring dan dikeringkan ulang. Perlakuan kedelai dengan pengukusan dan perebusan, dihaluskan, disaring dan dikeringkan. Proses pengeringan dilakukan bersamaan untuk semua perlakuan. Bubuk kedelai hasil perlakuan, dilakukan analisa yang meliputi, yaitu:

-Analisa Fisika, yaitu Densitas kamba (Kaur \& Singh, 2007) dan Wettability (Schuck, Zhang, Bhandari, \& Bansal, 2013).

-Analisa Kimia, yaitu Isoflavon (metoda HPLC), Kadar air (Metoda Oven), Protein

\section{Densitas Kamba (Kaur \& Singh, 2007)}

Densitas kamba adalah perbandingan bobot bahan dengan volume yang ditempatinya, termasuk ruang kosong diantara butiran bahan (Syarief \& Anis, 1999). Densitas kamba diukur dengan cara memasukkan bubuk kedelai ke dalam gelas ukur sampai volume tertentu tanpa dipadatkan, kemudian berat tepung ditimbang. Densitas kamba dihitung dengan cara membagi berat tepung dengan volume ruang yang ditempati. Densitas kamba dinyatakan dalam satuan $\mathrm{kg} / \mathrm{m} 3$ atau $\mathrm{g} / \mathrm{mL}$. 


\section{Wettability}

Pengukuran Wettability dilakukan dengan membasahi $10 \mathrm{~g}$ tepung ke dalam $100 \mathrm{ml}$ air bersuhu $20^{\circ} \mathrm{C}$. Waktu yang dibutuhkan untuk membasahi tepung dihitung sejak tepung dimasukkan kedalam air dan dinyatakan dengan satuan detik.

\section{HASIL DAN PEMBAHASAN}

Hasil pembahasan dari artikel Jurnal ini yakni Densi tas kamba (bulk density) merupakan densitas yang memperhatikan porositas (nonsolid). Densitas kamba sering digunakan sebagai parameter untuk merencanakan besar dan volume gudang penyimpanan, alat pengolahan, dan jenis pengemasan atau sarana transportasi.

Berdasarkan gambar 1 terlihat densitas kamba tertinggi diperoleh dari perlakuan kedelai tanpa pengolahan. Densitas kamba terendah diperoleh melalui proses perebusan. Hal ini disebabkan selama perebusan terjadi degradasi molekul polimer penyusun bahan seperti karbohidrat, protein dan lemak oleh enzim menjadi molekul yang sederhana dengan berat molekul lebih rendah sehingga densitas kamba menurun, semakin tinggi nilai densitas kamba menunjukkan produk semakin padat.

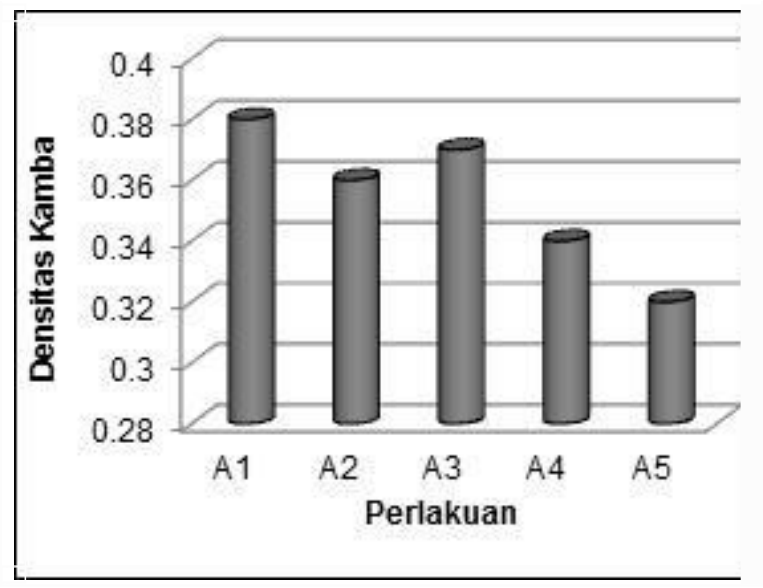

\section{Gambar 1. Hasil pengukuran densitas kamba kedelai bubuk tanpa pengolahan (A1), penyangraian ( A 2 ), perendaman ( A 3 ), pengukusan (A4), perebusan (A5)}

(Muchtadi, 1989) menambahkan, untuk kepentingan konsumsi bayi dibutuhkan jenis produk makanan tambahan yang memiliki kekambaan minimum, karena makanan, yang kambanya tinggi (bulky voluminous) tidak cocok untuk bayi mengingat kapasitas perut bayi yang masih terbatas. Sementara untuk produk tepung dengan skala besar, diharapkan memiliki densitas kamba yang cukup tinggi sehingga dapat mengurangi biaya tansportasi, distribusi, pengemasan dan gudang yang digunakan untuk penyimpanan (Marta, 2011).

\section{Wettability}

Wettabitly merupakan kemampuan partikel-partikel menyerap air pada permukaan, sifat wettabily sangan tergantung dengan sifat bahan. tergantung pada ukuran partikel bahan. Ukuran partikel bahan yang kecil akan merefleksikan luas permukaan yang besar sehingga memudahkan air untuk membasahi bahan yang lebih cepat dibandingkan bila ukuran partikel bahan lebih besar. Hasil pengukuran wettability kedelai bubuk seperti pada Gambar 2. 


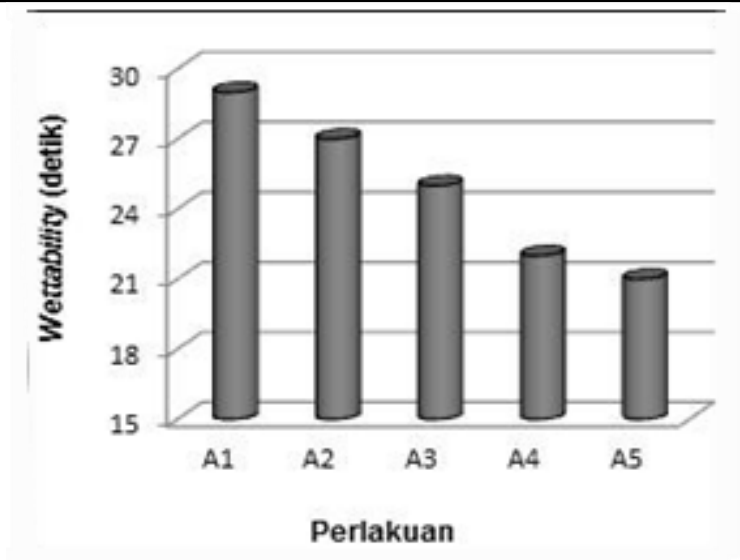

\section{Gambar 2. Hasil pengukuran wettability kedelai bubuk tanpa pengolahan ( A1 ), penyangraian ( A 2 ), Perendaman (A3), pengukusan (A4), perebusan (A5)}

Hasil pengukuran wettability perlakuan tanpa pengolahan membutuhkan waktu lebih lama untuk pembasahannya dibandingkan dengan perlakuan lainnya. Lamanya kedelai bubuk untuk dibasahi, dipengaruhi oleh densitas kambanya yang relatif besar. Bubuk kedelai dengan tekstur yang padat, memberikan ruang kosong yang tersisa diantara partikelpartikel bubuk lebih sedikit. Hal ini menyebabkan waktu yang dibutuhkan untuk membasahi seluruh permukaan bubuk menjadi lebih lama. Nilai wettability yang rendah merupakan indikator kecepatan homogenitas kedelai bubuk dalam proses pelarutan.

\section{Isoflavon}

Isoflavon merupakan golongan flavonoid yang terdapat dalam tanaman leguminose (kacang-kacangan) yang mempunyai kemampuan sebagai antioksidan dan mencegah terjadinya kerusakan sel akibat radikal bebas. Hasil penelitian yang dilakukan oleh (Kim et al., 2014), kandungan isoflavon kedelai dari 3 lokasi di Korea berkisar antara 0,002-2,435 $\mu$ mole/g. Kandungan isoflavon kedelai bubuk hasil analisis adalah seperti pada Gambar 3.

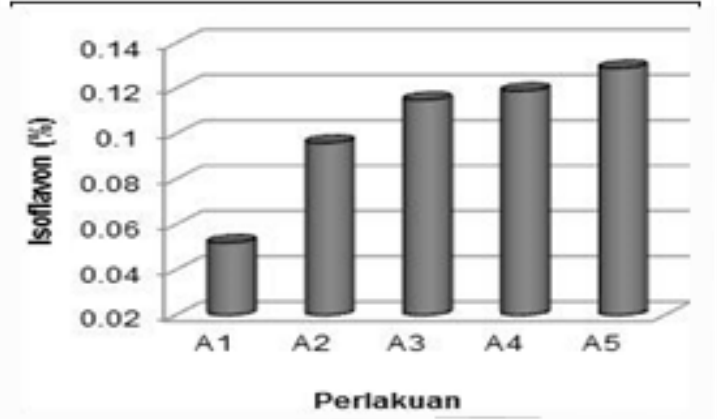

Gambar 3. Hasil analisis isoflavon kedelai bubuk tanpa pengolahan (A1), penyangraian (A 2), perendaman (A3), pengukusan (A4), perebusan (A5)

Dari gambar 3 terlihat bahwa kandungan isoflavon tertinggi diperoleh pada perlakuan perebusan biji kedelai yang berbeda nyata dengan perlakuan lainnya. Kedelai bubuk tanpa proses pengolahan mengandung senyawa isoflavon yang lebih rendah dibandingkan dengan kedelai bubuk dengan proses pengolahan seperti pengukusan, perebusan dan penyangraian

\section{Kadar Air, Protein dan Serat Kasar}

Kadar air merupakan salah satu parameter yang sangat berpengaruh terhadap umur simpan produk pangan. Kadar air suatu produk sangat penting dikendalikan karena akan menentukan daya tahan atau keawetan produk yang bersangkutan pada waktu penyimpanan. Kadar air tertinggi diperoleh pada perlakuan perebusan (A5) yaitu 5,29\%, dan terendah pada perlakuan penyanggraian kedelai (A2) yaitu 2,84\%. Hal ini disebabkan oleh 
perlakuan perebusan menyerap air yang lebih banyak selama pengolahan dilakukan. Hasil analisis kadar air, protein, dan serat kasar dari kedelai bubuk adalah seperti pada Gambar 4.

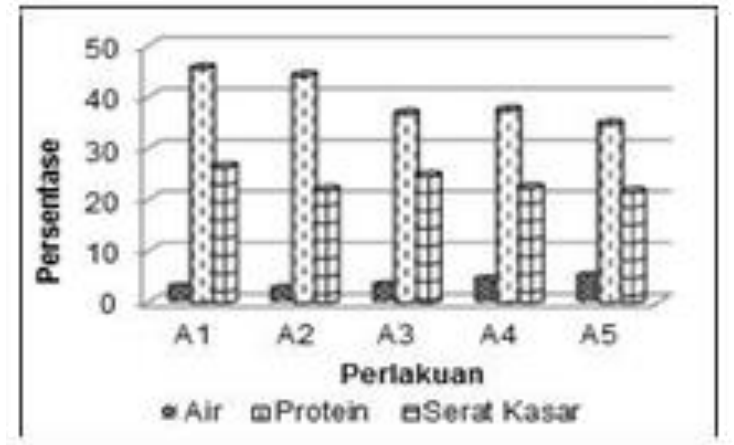

\section{Gamar 4. Hasil analisis kadar air, protein dan serat kasar kedelai bubuk tanpa pengolahan (A1), penyangraian (A 2), perendaman (A3), pengukusan (A4), perebusan (A5)}

Dari Gambar 4 juga terlihat bahwa kadar protein dari kedelai bubuk tanpa pengolahan (A1) adalah 45,57\% yang lebih tinggi dibandingkan dengan kedelai bubuk yang mengalami proses pengolahan. Proses pengolahan menyebabkan protein bahan terdenaturasi sehingga kemampuan mengikat air menurun dan adanya energi panas dapat mengakibatkan terputusnya interaksi non kovalen pada struktur alami protein (Gilang, Affandi, \& Ishartani, 2013). Namun demikian, proses pengolahan dapat meningkatkan daya cerna protein dan protease inhibitor (Revilla, 2015). Menurut (de Lima et al., 2014), kadar protein turun karena lepasnya ikatan struktur protein selama perendaman sehingga komponen protein larut dalam air. Kandungan protein pada kedelai kering adalah sekitar 40\%, yang terdiri dari lipoksigenase, b-amilase, lektin dan inhibitor tripsin (Nishinari, Fang, Guo, \& Phillips, 2014).

Proses pemanasan menyebabkan protein yang tersusun dari beberapa asam amino yang mempunyai gugus reaktif akan berikatan dengan komponen lain seperti gula pereduksi yang menyebabkan reaksi Mailard. Reaksi Mailard dapat merusak lisin dan sistein, menurunkan ketersediaan semua asam- asam amino termasuk isoleusin yang paling stabil (Palupi et al., 2007).

Kadar serat kasar tertinggi dari kedelai bubuk diperoleh pada perlakuan tanpa pengolahan yaitu 26,34\% dan terendah pada kedelai bubuk melalui proses perebusan $21,49 \%$ dan penyangraian 21,85\%. Dari Gambar 4 terlihat bahwa proses pengolahan dapat menurunkan kandungan serat dari kedelai bubuk. Seperti halnya komoditi pertanian lainnya, contohnya apel yang diolah menjadi saus akan menurunkan seratnya sampai 2,4-1,7 gram/10o gram buah segar dan fraksi larut meningkat (Colin-Henrion, Mehinagic, Renard, Richomme, \& Jourjon, 2009).

\section{KESIMPULAN}

1. Perlakuan proses pengolahan yang dilakukan dalam pembuatan kedelai bubuk memberikan pengaruh yang nyata terhadap sifat fisika (densitas kamba, wettability), dan sifat kimia (isoflavon, kadar air, protein, dan serat kasar).

2. Proses pengolahan, perendaman, penyangraian, pengukusan dan perebusan akan menurunkan densitas kamba, wettability, kadar protein dan serat kasar, tetapi menaikkan kandungan isoflavon dan kadar air dari kedelai bubuk yang dihasilkan.

\section{BIBLIOGRAFI}

Cederroth, Christopher R., \& Nef, Serge. (2009). Soy, phytoestrogens and metabolism: A review. Molecular and Cellular Endocrinology, 304(1-2), 30-42. Google Scholar

Colin-Henrion, Muriel, Mehinagic, Emira, Renard, Catherine M. G. C., Richomme, Pascal, \& Jourjon, Frédérique. (2009). From apple to applesauce: Processing effects on dietary 
Gede Yohanes Arygunartha, Ni Luh Putu Putri Setianingsih, Sofia Utami Putri Sunarso Pengaruh Proses Pengolahan terhadap Sifat Fisika dan Kimia Bubuk Kedelai: Literature Review

fibres and cell wall polysaccharides. Food Chemistry, 117(2), 254-260. Google Scholar

de Lima, Fernando Sanches, Kurozawa, Louise Emy, \& Ida, Elza Iouko. (2014). The effects of soybean soaking on grain properties and isoflavones loss. LWT-Food Science and Technology, 59(2), 1274-1282. Google Scholar

Gilang, Retna, Affandi, Dian Rachmawanti, \& Ishartani, Dwi. (2013). Karakteristik fisik dan kimia tepung koro pedang (Canavalia ensiformis) dengan variasi perlakuan pendahuluan. Jurnal Teknosains Pangan, 2(3). Google Scholar

Kaur, Maninder, \& Singh, Narpinder. (2007). Relationships between various functional, thermal and pasting properties of flours from different Indian black gram (Phaseolus mungo L.) cultivars. Journal of the Science of Food and Agriculture, 87(6), 974-984. Google Scholar

Kim, Eun Hye, Lee, Oh Kyu, Kim, Jae Kwang, Kim, Sun Lim, Lee, Joohyun, Kim, Seung Huyn, \& Chung, Ill Min. (2014). Isoflavones and anthocyanins analysis in soybean (Glycine max (L.) Merill) from three different planting locations in Korea. Field Crops Research, 156, 76-83. Google Scholar

Marta, Herlina. (2011). Sifat fungsional dan reologi tepung jagung nikstamal serta aplikasinya pada pembuatan makanan pendamping ASI. Google Scholar

Muchtadi, T. R. (1989). Pengetahuan Bahan Pangan. PAU Pangan Dan Gizi. Institut Pertanian Bogor, Bogor. Google Scholar

Nishinari, K., Fang, Y., Guo, S., \& Phillips, G. O. (2014). Soy proteins: A review on composition, aggregation and emulsification. Food Hydrocolloids, 39, 301-318. Google $\underline{\text { Scholar }}$

Palupi, N. S., Zakaria, F. R., \& Prangdimurti, E. (2007). Pengaruh pengolahan terhadap nilai gizi pangan. Modul E-Learning ENBP, Departemen Ilmu \& Teknologi Pangan-Fateta$I P B, 1-14$. Google Scholar

Revilla, Isabel. (2015). Impact of thermal processing on faba bean (Vicia faba) composition. In Processing and impact on active components in food (pp. 337-343). Elsevier. Google Scholar

Schuck, Pierre, Zhang, M., Bhandari, B., \& Bansal, N. (2013). Handbook of food powders. UK: Woodhead Publishing Limited. Haettu, 16, 2020. Google Scholar

Shimelis, Emire Admassu, \& Rakshit, Sudip Kumar. (2007). Effect of processing on antinutrients and in vitro protein digestibility of kidney bean (Phaseolus vulgaris L.) varieties grown in East Africa. Food Chemistry, 103(1), 161-172. Google Scholar

Sukandar, E. Y., Permana, H., Adnyana, I. K., Sigit, J. I., Ilyas, R. A., Hasimun, P., \& Mardiyah, D. (2010). Clinical study of turmeric (Curcuma longa L.) and garlic (Allium sativum L.) extracts as antihyperglycemic and antihyperlipidemic agent in type-2 diabetes-dyslipidemia patients. IJP-International Journal of Pharmacology, 6(4), 456-463. Google Scholar

Syarief, \& Anis. (1999). Teknologi Proses Pengolahan Pangan. Bogor: PAU Pangan dan Gizi IPB. Google Scholar 